\title{
PENGARUH LIKUIDITAS, SOLVABILITAS, MANAJEMEN ASET, dan UKURAN PERUSAHAAN TERHADAP KINERJA KEUANGAN
}

\author{
Lely Diana \\ Maria Stefani Osesoga* \\ Universitas Multimedia Nusantara, Jalan Scientia Boulevard, Gading, Serpong, Tangerang, Banten \\ maria.stefani@umn.ac.id
}

\author{
A R T I C L E I N F O \\ Article history: \\ Received December 10, 2019 \\ Revised January 07, 2020 \\ Accepted January 07, 2020
}

Key words:

Financial Performance, Firm Size, Liquidity, Management Asset, Solvency

DOI:

10.33508/jako.v12i1.2282

\begin{abstract}
A B S T R A C T
Financial performance refers to companies' capability which is showed in financial report and used for decision making by stakeholders. The purpose of this research was to obtain empirical evidence about the effect of liquidity, solvency, management asset, and firm size towards financial performance. The objects were manufacturing companies listed in Indonesia Stock Exchange (IDX) for period 2015-2018. The sample was selected by using purposive sampling method and was analyzed by using multiple regression method. The result of this research were (1) liquidity have significant effect towards financial performance, (2) solvency does not have effect towards financial performance, (3) management asset have significant effect towards financial performance, and (4) firm size have significant effect towards financial performance.
\end{abstract}

\begin{abstract}
A B S T R A K
Kinerja keuangan mengacu pada kemampuan perusahaan yang ditunjukkan dalam laporan keuangan dan digunakan untuk pengambilan keputusan oleh pemangku kepentingan. Tujuan dari penelitian ini adalah untuk mendapatkan bukti empiris tentang pengaruh likuiditas, solvabilitas, aset manajemen, dan ukuran perusahaan terhadap kinerja keuangan. Objek dalam penelitian ini adalah perusahaan manufaktur yang terdaftar di Bursa Efek Indonesia (BEI) untuk periode 2015-2018. Sampel dipilih dengan menggunakan metode purposive sampling dan dianalisis dengan menggunakan metode regresi berganda. Hasil penelitian ini adalah (1) likuiditas berpengaruh signifikan terhadap kinerja keuangan, (2) solvabilitas tidak berpengaruh terhadap kinerja keuangan, (3) aset manajemen berpengaruh signifikan terhadap kinerja keuangan, dan (4) ukuran perusahaan berpengaruh signifikan terhadap kinerja keuangan.
\end{abstract}

\section{PENDAHULUAN}

Berdasarkan data publikasi Badan Koordinasi Penanaman Modal (BKPM), realisasi investasi Penanaman Modal Dalam Negeri (PMDN) dan Penanaman Modal Asing (PMA) 2018 terus mengalami peningkatan dibandingkan dengan tahun 2017. Pada Triwulan I tahun 2018 total realisasi investasi meningkat sebesar $11,76 \%$, pada Triwulan II meningkat sebesar 3,16\%, pada Triwulan III mengalami penurunan sebesar $1,59 \%$, dan pada Triwulan IV mengalami peningkatan sebesar 3,51\% dari tahun 2017. Meskipun belum berhasil mencapai target realisasi investasi tahun 2018 sebesar Rp 765 triliun, secara keseluruhan realisasi investasi masih mengalami peningkatan dari tahun 2017 yaitu senilai Rp 692,8 triliun menjadi Rp 721,3 triliun pada tahun 2018 (Badan Koordinasi Penanaman Modal, 2018).

Pada Triwulan IV tahun 2018 total realisasi investasi kembali mengalami peningkatan dibandingkan tahun 2017 yaitu dari angka Rp 179,6 triliun menjadi Rp 185,9 triliun. Meskipun terjadi fluktuasi realisasi investasi selama tahun 2018, secara keseluruhan kegiatan investasi di Indonesia masih terus mengalami peningkatan dari tahun sebelumnya (Badan Koordinasi Penanaman Modal, 2018). Kondisi perkembangan realisasi investasi Indonesia dapat dilihat dalam Gambar 1 sebagai berikut:

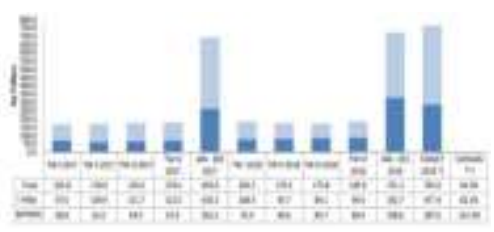

Gambar 1. Perkembangan Realisasi Investasi Indonesia Periode 2017-2018

Sumber: Badan Koordinasi Penanaman Modal, 2018 
Di Indonesia, minat investor melakukan investasi terus mengalami peningkatan. Hal itu salah satunya ditandai dengan meningkatnya jumlah Single Investor Identification (SID) dari tahun 2012 sampai dengan akhir tahun 2018. Investor diwajibkan memiliki SID sejak 2012, sesuai dengan Keputusan Ketua Badan Pengawas Pasar Modal dan Lembaga Keuangan No. KEP-327/BL/2012. Gambar 2 menunjukkan pertumbuhan jumlah SID tahun 2012-26 Desember 2016:

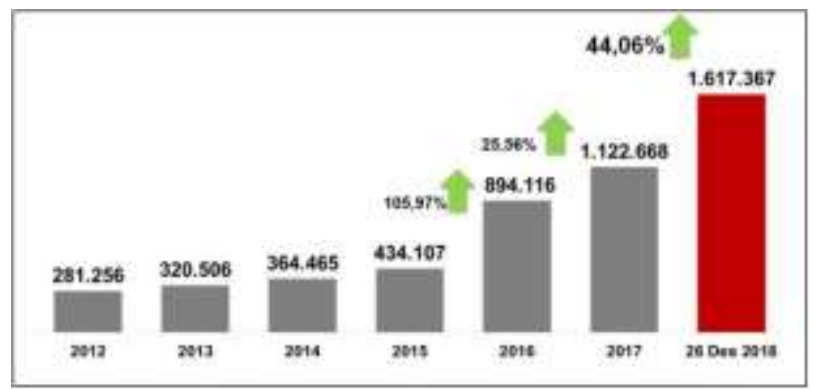

Gambar 2. Pertumbuhan Jumlah SID tahun 201226 Desember 2018

Sumber: Kustodian Sentral Efek Indonesia, 2018

Berdasarkan Gambar 2, tahun 2012 jumlah SID atau investor pasar modal Indonesia tercatat sebesar 281.256 dan pada akhir tahun 2018 sebanyak 1.617.367. Dari data tersebut dapat dikatakan jumlah investor pasar modal Indonesia mengalami pertumbuhan. Semakin bertambahnya jumlah investor pasar modal dapat dimanfaatkan oleh perusahaan untuk mendapatkan dana atau modal tambahan dari pihak eksternal. Dalam pengambilan keputusan berinvestasi, pihak eksternal mempertimbangkan kinerja keuangan yang tercantum dalam laporan keuangan karena semakin efisien kinerja keuangan suatu perusahaan maka diharapkan perusahaan akan dapat menghasilkan laba yang maksimal dan dapat memberikan return sehingga akan menarik investor untuk melakukan investasi. Menurut Jumingan (2006), kinerja keuangan adalah cerminan dari seberapa baik pengelolaan perusahaan yang mengacu pada laporan keuangan yang telah dipublikasikan pada suatu periode tertentu yang biasanya diukur dari aspek kecukupan modal, likuiditas, dan profitabilitas. Seberapa baik kinerja keuangan suatu perusahaan dapat dilihat dari informasi yang ada pada laporan keuangan yang dimiliki. Informasi yang terdapat dalam laporan keuangan dapat menjadi salah satu dasar bagi pengguna laporan keuangan untuk melihat kinerja keuangan perusahaan di masa sebelumya sehingga dapat memprediksikan bagaimana kinerja keuangan ke depannya.
Pentingnya kinerja keuangan dapat dirasakan oleh berbagai pihak. Bagi perusahaan, semakin efisien kinerja keuangan perusahaan menggambarkan keberhasilan dalam pencapaian tujuan perusahaan menghasilkan laba. Hal itu dapat dimanfaatkan oleh manajer sebagai dasar pengambilan keputusan, baik dalam melakukan investasi, memaksimalkan operasional, dan pembagian sejumlah keuntungan kepada pemegang saham. Bagi pihak eksternal perusahaan, kinerja keuangan perusahaan juga menjadi aspek penting dalam pengambilan keputusan. Investor tentunya akan lebih tertarik melakukan investasi terhadap perusahaan dengan kinerja keuangan yang baik. Perusahaan dengan kinerja keuangan yang baik merupakan perusahaan yang dapat menghasilkan laba semaksimal mungkin sehingga diharapkan memiliki tingkat pengembalian yang tinggi. Sebagai penanam modal, semakin maksimal kinerja keuangan perusahaan menandakan semakin efisien tingkat pengelolaan perusahaan dan diharapkan akan dapat menghasilkan laba yang tinggi sehingga dapat memberikan return yang menguntungkan bagi investor. Sebagai contoh, harga saham PT Akasha Wira International Tbk (ADES) melompat tinggi sebesar $16 \%$ menjadi Rp 1.540 pada tanggal 10 Mei 2012 karena aktivitas pemborongan saham. Disinyalir, kegiatan investor membeli saham ini terkait dengan kinerja cemerlang perusahaan. Sepanjang kuartal pertama tahun 2012, laba bersih ADES melonjak tiga kali lipat menjadi Rp 13,45 miliar dari sebelumnya $\mathrm{Rp} 3,54$ miliar dibanding periode yang sama tahun sebelumnya. Hal tersebut menunjukkan kinerja keuangan yang baik dapat meningkatkan minat investor untuk menanamkan modalnya ke perusahaan (Taqiyyah, 2012).

Bagi pihak bank atau kreditur, kinerja keuangan yang baik menandakan semakin baik pengelolaan operasional perusahaan dalam menghasilkan laba yang maksimal sehingga memberikan jaminan kesanggupan perusahaan untuk membayar utang beserta bunga dan dapat meyakinkan pihak bank atau kreditur untuk memberikan kredit kepada perusahaan. Kinerja keuangan perusahaan juga bermanfaat bagi penghasilan negara berupa pajak, yang merupakan sumber utama pendapatan negara. Semakin baik kinerja keuangan perusahaan yang ditandai dengan semakin tinggi laba yang dihasilkan perusahaan, maka semakin banyak dana yang akan diterima pemerintah sebagai modal penggerak perekonomian negara. Industri manufaktur berperan membawa multiplier effect pada perekonomian nasional seperti penyerapan tenaga kerja, peningkatan nilai tambah bahan baku dalam 
negeri, meningkatkan nilai investasi dan penerimaan negara dari ekspor sehingga menjadi sektor andalan untuk mengakselerasi pertumbuhan ekonomi nasional. Saat ini, sektor industri berkontribusi terhadap PDB sebesar 20\%, kemudian untuk perpajakan sekitar 30\%, dan ekspor hingga $74 \%$. Capaian ini yang terbesar disumbangkan dari lima sektor manufaktur yaitu industri makanan dan minuman, industri tekstil dan pakaian, industri otomotif, industri kimia, dan industri elektronika (Hardum, 2019). Sebagai bentuk dukungan terhadap kinerja perekonomian Indonesia yang semakin baik, Warta Ekonomi memberikan apresiasi kepada 29 perusahaan terbuka (emiten) sektor manufaktur yang telah berhasil memiliki tingkat perdagangan saham dan kinerja keuangan yang baik, antara lain Astra International Tbk, Unilever Indonesia Tbk, dan Gudang Garam Tbk. Penghargaan ini diberikan berdasarkan kinerja fundamental emiten (analisis kinerja keuangan perusahaan), yaitu perusahaan yang konsisten menghasilkan profit, bahkan berhasil mengalami pertumbuhan profit, serta memiliki kinerja dan kemampuan efisiensi baik, yang dapat diukur dari Return On Assets (ROA) (Rahayu, 2018).

Kinerja keuangan suatu perusahaan dapat diukur dengan rasio profitabilitas. Investor juga cenderung menilai berdasarkan rasio profitabilitas, rasio tersebut menggambarkan kemampuan perusahaan memperoleh laba dalam hubungannya dengan penjualan, total aktiva maupun modal sendiri (Utami dan Pardanawati, 2016). Dalam penelitian ini profitabilitas diukur dengan menggunakan rasio Return On Asset (ROA). Pengukuran kinerja keuangan menggunakan ROA menunjukkan kemampuan operasional perusahaan untuk menghasilkan laba menggunakan aset yang dimiliki. ROA yang tinggi menunjukkan semakin tinggi kemampuan perusahaan untuk menghasilkan laba dari aset yang dimiliki. Hal ini menandakan bahwa kinerja keuangan perusahaan yang baik berbanding lurus dengan tingkat ROA yang tinggi.

Faktor-faktor yang dapat mempengaruhi kinerja keuangan antara lain likuiditas, solvabilitas, manajemen aset, dan ukuran perusahaan. Likuiditas adalah rasio yang menunjukkan kemampuan perusahaan untuk memenuhi kewajiban finansial yang berjangka pendek tepat pada waktunya (Utami dan Pardanawati, 2016). Dalam penelitian ini tingkat likuiditas diukur dengan menggunakan Current Ratio (CR). Current ratio merupakan rasio yang menunjukkan tingkat kemampuan perus- ahaan melunasi utang jangka pendeknya menggunakan aset lancar yang dimiliki. Semakin tinggi CR atau semakin likuid perusahaan, menunjukkan tingginya tingkat kemampuan untuk melunasi utang jangka pendek yang ada dengan menggunakan aset lancar yang dimiliki. Tingginya aset lancar menunjukkan ketersediaan dana jangka pendek yang dapat digunakan selain untuk melunasi utang jangka pendek, juga dapat digunakan untuk mendukung kegiatan operasional perusahaan dalam meningkatkan penjualan guna menghasilkan laba. Dengan laba yang tinggi diikuti pengelolaan aset yang efisien, maka nilai ROA diharapkan akan tinggi. Semakin tinggi tingkat likuiditas suatu perusahaan maka semakin efisien kinerja keuangan perusahaan. Hal ini sesuai dengan penelitian yang telah dilakukan oleh Utami dan Pardanawati (2016), Alicia (2017), serta Saragih, dkk. (2015) yang menyatakan bahwa likuiditas memiliki pengaruh positif dan signifikan terhadap kinerja keuangan. Namun, hasil penelitian ini tidak sejalan dengan penelitian yang dilakukan oleh Tjahjono (2014) yang menyatakan bahwa likuiditas tidak berpengaruh terhadap kinerja keuangan.

Solvabilitas merupakan kemampuan suatu perusahaan dalam membayar kewajiban jangka panjang jika perusahaan dilikuidasi (Darsono, dkk., 2005; dalam Sabil, 2016). Tingkat solvabilitas diukur dengan Debt to Total Asset Ratio (DTA). Rasio tersebut menunjukkan seberapa besar aset perusahaan yang dibiayai oleh utang. Semakin tinggi tingkat solvabilitas, yaitu ditandai dengan tingkat DTA yang rendah menandakan semakin sedikit aset yang diperoleh perusahaan dengan menggunakan utang. Semakin sedikit jumlah utang dan beban bunga yang ditanggung perusahaan mengakibatkan dana yang dimiliki perusahaan selain untuk melunasi utang dan beban bunga, juga dapat dialokasikan ke kegiatan operasional perusahaan. Dalam operasional, dana yang ada digunakan untuk membeli aset perusahaan yang akan dikelola untuk memperoleh penjualan guna memperoleh laba. Laba yang tinggi disertai dengan pengelolaan aset yang efisien akan menghasilkan tingkat ROA yang tinggi. Semakin tinggi tingkat solvabilitas yang ditandai dengan semakin rendah nilai DTA maka semakin efisien kinerja keuangan perusahaan. Hal ini didukung oleh penelitian sebelumnya yang dilakukan oleh Isbanah (2015), Supardi, dkk. (2016), dan Gunde, dkk. (2017) yang menyatakan bahwa solvabilitas/leverage memiliki pengaruh negatif terhadap kinerja keuangan. Namun, penelitian yang dilakukan oleh Utami dan 
Pandanawati (2016), serta Tjahjono (2014), menyatakan solvabilitas tidak memiliki pengaruh terhadap kinerja keuangan.

Rasio aktivitas menurut Raharjaputra (2009) merupakan rasio yang mengukur seberapa efektif (hasil guna) perusahaan menggunakan sumber dayanya. Dari rasio aktivitas ini dapat digunakan untuk menilai kemampuan manajemen aset perusahaan. Dalam penelitian ini manajemen aset diukur dengan menggunakan Total Asset Turnover (TATO). Rasio tersebut menunjukkan tingkat keberhasilan total aset yang dimiliki untuk menghasilkan penjualan. Semakin tinggi rasio aktivitas atau semakin tinggi tingkat TATO perusahaan yang berarti semakin baiknya manajemen aset yang ditandai dengan semakin cepat perputaran operasional aset perusahaan menghasilkan penjualan. Angka penjualan yang tinggi dan disertai dengan penggunaan beban yang efisien, maka perusahaan akan menghasilkan laba yang tinggi. Laba yang tinggi dan pengelolaan aset yang efisien maka akan menghasilkan nilai ROA yang tinggi. Dengan demikian, semakin efisien manajemen aset yang ditandai dengan semakin tinggi nilai TATO maka semakin efisien juga kinerja keuangan perusahaan. Hal ini didukung oleh penelitian yang dilakukan oleh Utami dan Pardanawati (2016), Indriyani, dkk. (2017), dan Sinaga (2018) yang menyatakan rasio aktivitas berpengaruh positif terhadap kinerja keuangan. Namun hal ini bertentangan dengan hasil penelitian Mulyani dan Budiman (2017) yang menyatakan bahwa rasio aktivitas berpengaruh negatif terhadap kinerja keuangan. Sedangkan hasil penelitian Noormuliyaningsih dan Swandari (2016), menyatakan TATO tidak berpengaruh signifikan terhadap ROA.

Kinerja keuangan juga dapat dipengaruhi oleh ukuran perusahaan. Ukuran perusahaan merupakan nilai yang menunjukan besar kecilnya perusahaan (Indarti dan Extralyus, 2013; dalam Tisna dan Agustami, 2016). Dalam penelitian ini ukuran perusahaan diukur menggunakan logaritma natural total aset. Berdasarkan Peraturan Otoritas Jasa Keuangan tentang Pernyataan Pendaftaran dalam Rangka Penawaran Umum dan Penambahan Modal dengan Memberikan Hak Memesan Efek Terlebih Dahulu oleh Perusahaan dengan Aset Skala Kecil atau Perusahaan dengan Aset Skala Menengah, perusahaan dengan aset skala kecil adalah badan hukum yang didirikan di Indonesia yang memiliki total aset tidak lebih dari Rp.50.000.000.000,00 (lima puluh miliar rupiah) dan Perusahaan dengan aset skala menengah memiliki total aset lebih dari Rp. 50.000.000.000,00 (lima puluh miliar rupiah) sampai dengan Rp.250.000.000.000,00 (dua ratus lima puluh miliar rupiah).

Semakin besar ukuran suatu perusahaan menunjukkan semakin banyak jumlah total aset yang dimiliki, yang berarti semakin tinggi tingkat kemampuan perusahaan mengelola asetnya dalam kegiatan operasional perusahaan untuk menghasilkan laba. Tingginya tingkat laba yang dihasilkan disertai pengelolaan aset yang efisien maka akan menghasilkan ROA yang tinggi. Dengan demikian, semakin besar ukuran perusahaan maka semakin efisien kinerja keuangan perusahaan. Hal ini didukung dalam penelitian Tisna dan Agustami (2016) yang menyatakan bahwa ukuran perusahaan memiliki pengaruh positif terhadap kinerja keuangan, penelitian Isbanah (2015) ukuran perusahaan berpengaruh negatif terhadap kinerja keuangan, dan penelitian Epi (2017) yang menyatakan bahwa ukuran perusahaan tidak berpengaruh terhadap kinerja keuangan.

Beragamnya hasil penelitian terkait pengaruh likuiditas, solvabilitas, manajemen aset, dan ukuran perusahaan terhadap kinerja keuangan mendorong peneliti untuk kembali membuktikan pengaruh likuiditas, solvabilitas, manajemen aset, dan ukuran perusahaan terhadap kinerja keuangan perusahaan. Tujuan penelitian ini adalah untuk memperoleh bukti empiris mengenai pengaruh likuiditas, solvabilitas, manajemen aset, dan ukuran perusahaan terhadap kinerja keuangan pada perusahaan manufaktur yang terdaftar di BEI periode 2015-2018.

\section{KAJIAN LITERATUR DAN PENGEMBANGAN HIPOTESIS}

\section{Laporan Keuangan}

Laporan keuangan adalah penyajian terstruktur dari posisi keuangan dan kinerja keuangan dalam sebuah entitas. Tujuan laporan keuangan adalah untuk memberikan informasi tentang posisi keuangan, kinerja, dan arus kas suatu entitas yang bermanfaat bagi beragam pengguna laporan dalam membuat keputusan ekonomi. Laporan keuangan lengkap terdiri dari laporan posisi keuangan pada akhir periode, laporan laba rugi dan penghasilan komprehensif lain selama periode, laporan perubahan ekuitas selama periode, laporan arus kas selama periode, catatan atas laporan keuangan, dan Laporan posisi keuangan pada awal periode komparatif yang disajikan ketika entitas menerapkan suatu kebijakan akuntansi secara retrospektif atau membuat penyajian kembali pos-pos laporan keuangan, atau ketika entitas mereklasifikasi pos- 
pos dalam laporan keuangannya (Ikatan Akuntan Indonesia, 2018).

\section{Kinerja Keuangan}

Kinerja keuangan adalah penentuan ukuranukuran tertentu yang dapat mengukur keberhasilan suatu perusahaan dalam menghasilkan laba (Tjahjono, 2014). Terdapat tiga alat yang dapat digunakan dalam menganalisa laporan keuangan, yaitu dengan analisa horizontal (membandingkan data keuangan pada periode yang berbeda), analisa vertikal (membandingkan item laporan keuangan dengan basis persentase pada satu periode), dan analisa rasio (menggambarkan hubungan antara pos-pos dalam laporan keuangan). Kinerja keuangan perusahaan dapat diukur dengan menggunakan rasio-rasio yang terdapat dalam laporan keuangan perusahaan yang dikeluarkan secara periodik (Solechan, 2017).

Kieso, dkk. (2017) mengklasifikasikan rasio untuk menganalisis laporan keuangan yaitu: liquidity ratios untuk mengukur kemampuan jangka pendek perusahaan untuk melunasi kewajiban yang dimiliki sebelum jatuh tempo, activity ratios untuk mengukur seberapa efektif perusahaan mengelola aset yang dimiliki, profitability ratios untuk mengukur tingkat keberhasilan atau kegagalan suatu perusahaan dalam jangka waktu yang ditentukan, dan coverage ratios untuk mengukur tingkat perlindungan bagi kreditur dan investor jangka panjang. Dalam penelitian ini kinerja keuangan diproksikan menggunakan Return On Asset (ROA). ROA adalah rasio yang digunakan untuk mengukur kemampuan perusahaan dalam menghasilkan laba bersih berdasarkan tingkat aset tertentu (Fajrin dan Laily, 2016). Tingkat ROA yang tinggi menggambarkan semakin baik kinerja keuangan perusahaan.

\section{$\underline{\text { Likuiditas }}$}

Rasio likuiditas adalah rasio yang menunjukkan kemampuan perusahaan untuk memenuhi kewajiban finansial yang berjangka pendek tepat pada waktunya (Utami dan Pardanawati 2016). Sehingga jika perusahaan memiliki likuiditas yang tinggi maka perusahaan akan dapat melunasi utang- utang jangka pendeknya. Dalam penelitian ini digunakan Current Ratio (CR) untuk mengukur tingkat likuiditas perusahaan. Hantono (2016) menyatakan current ratio menunjukkan sejauh mana aktiva lancar menutupi kewajiban-kewajiban lancar.

Semakin besar perbandingan aktiva lancar dan kewajiban lancar semakin tinggi kemampuan pe- rusahaan menutupi kewajiban jangka pendeknya. Current ratio yang rendah biasanya dianggap menunjukkan terjadinya masalah dalam likuidasi, sebaliknya current ratio yang terlalu tinggi juga kurang bagus, karena menunjukkan banyaknya dana menganggur yang pada akhirnya dapat mengurangi kemampuan laba perusahaan (Hantono, 2016). Menurut Syamsuddin (2009, dalam Novitasari dan Herlambang, 2015) "...tingkat current ratio 2,00 sudah dianggap baik (concidered acceptable)". Hasil penelitian Utami dan Pardanawati (2016) serta Mulyani dan Budiman (2017) menyatakan bahwa likuiditas berpengaruh positif dan signifikan terhadap kinerja keuangan, sedangkan penelitian Tjahjono (2014) menyatakan bahwa likuiditas tidak berpengaruh terhadap kinerja keuangan.

\section{$\mathrm{Ha}_{1}$ : Likuiditas berpengaruh terhadap kinerja keuangan}

\section{Solvabilitas}

Rasio solvabilitas merupakan rasio yang mengukur kemampuan perusahaan untuk bertahan dalam periode jangka panjang (Weygandt, dkk. 2015). Dalam penelitian ini solvabilitas diukur dengan menggunakan Debt to Total Assets Ratio (DTA). Menurut Gunde, dkk. (2017) debt to total assets ratio mengukur seberapa besar jumlah aktiva perusahaan yang dibiayai dengan hutang atau seberapa besar hutang perusahaan berpengaruh terhadap pengelolaan aktiva.

Semakin tinggi DTA berarti semakin besar sumber dana yang dimiliki melalui pinjaman digunakan untuk membiayai aktiva. Semakin besar DTA menunjukkan semakin besar tingkat ketergantungan perusahaan terhadap pihak eksternal (kreditur) dan semakin besar beban biaya hutang (biaya bunga) yang harus dibayar sehingga akan menurunkan laba yang diperoleh. Hasil penelitian Gunde, dkk. (2017) dan Akbar, dkk. (2017) menyatakan solvabilitas memiliki pengaruh terhadap kinerja keuangan, berbeda dengan penelitian Utami dan Pandanawati (2016), serta Tjahjono (2014), menyatakan solvabilitas tidak memiliki pengaruh terhadap kinerja keuangan.

\section{$\mathrm{Ha}_{2}$ : Solvabilitas berpengaruh terhadap kinerja} keuangan

\section{Manajemen Aset}

Rasio aktivitas menggambarkan aktivitas yang dilakukan perusahaan dalam menjalankan operasinya baik dalam kegiatan penjualan, pembelian, dan mengukur efektivitas perusahaan da- 
lam rangka memanfaatkan sumber daya yang dimilikinya melalui kegiatan operasinya. Utami dan Pardanawati (2016) menjelaskan bahwa dari rasio aktivitas bisa menilai manajemen aset perusahaan. Dalam penelitian ini, manajemen aset diukur dengan menggunakan rasio Total Assets Turnover (TATO). Menurut Indriyani, dkk. (2017), total assets turnover adalah kemampuan perusahaan menghasilkan penjualan berdasarkan efektivitas penggunaan total aktiva.

Semakin tinggi perputaran total aktiva berarti semakin efektif penggunaan aset tersebut. Menurut Sinaga (2018) perputaran aset yang tinggi menandakan bahwa perusahaan efektif dalam memanfaatkan sumber daya yang menghasilkan laba. Semakin tinggi perputaran, maka akan memperbesar nilai penjualan/pendapatan perusahaan yang mengakibatkan laba perusahaan meningkat. Hasil penelitian Sinaga (2018) menyatakan TATO berpengaruh terhadap ROA, penelitian Mulyani dan Budiman (2017) menyatakan bahwa rasio aktivitas mempunyai pengaruh negatif terhadap kinerja keuangan, sedangkan penelitian Noormuliyaningsih dan Swandari (2016), menyatakan TATO tidak berpengaruh signifikan terhadap ROA.

$\mathrm{Ha}_{3}$ : Manajemen Aset berpengaruh terhadap kinerja keuangan.

\section{Ukuran Perusahaan}

Ukuran perusahaan merupakan nilai yang menunjukkan besar kecilnya perusahaan (Indarti dan Extralyus, 2013; dalam Tisna dan Agustami, 2016). Ukuran perusahaan diukur berdasarkan besarnya logaritma natural total aset yang dimiliki perusahaan. Penggunaan logaritma natural digunakan untuk mengurangi fluktuasi data. Dengan logaritma natural, nilai total aset akan disederhanakan tanpa mengubah proporsi dari nilai yang sebenarnya.

Semakin maksimal aktiva perusahaan maka laba yang akan didapat menjadi maksimal pula, karena aktiva perusahaan digunakan oleh perusahaan untuk kegiatan operasional perusahaan yang tujuannya untuk menghasilkan laba (Ambarwati, dkk. (2015). Hasil penelitian Tisna dan Agustami (2016) menyimpulkan bahwa ukuran perusahaan berpengaruh terhadap kinerja keuangan perusahaan, penelitian Isbanah (2015) menyatakan ukuran perusahaan berpengaruh negatif terhadap kinerja keuangan, sedangkan menurut penelitian Epi (2017) ukuran perusahaan tidak mempunyai pengaruh terhadap kinerja keuangan.

Ha: Ukuran Perusahaan (UP) berpengaruh terhadap kinerja keuangan.

\section{Model Penelitian}

Model penelitian yang digunakan dalam penelitian ini adalah sebagai berikut:

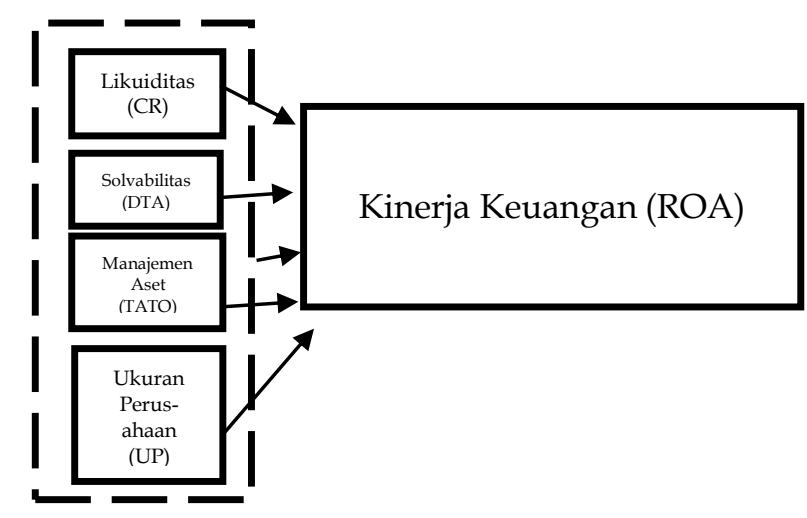

Gambar 3. Model Penelitian

\section{METODE PENELITIAN}

Dalam penelitian ini, objek yang diteliti adalah perusahaan manufaktur yang terdaftar di BEI periode 2015-2018. Data yang digunakan adalah data sekunder berupa laporan keuangan perusahaan yang diperoleh dari situs resmi BEI, yaitu www.idx.co.id dan website resmi perusahaan. Teknik pengambilan sampel yang digunakan adalah purposive sampling.

\section{Variabel Penelitian}

a. Variabel Dependen

Variabel dependen yang digunakan dalam penelitian ini adalah kinerja keuangan yang diproksikan dengan Return On Asset (ROA). Kinerja keuangan merupakan ukuran prestasi keberhasilan suatu perusahaan yang dilaporkan dalam laporan keuangan. ROA adalah rasio yang digunakan untuk mengukur kemampuan aset perusahaan dalam menghasilkan laba. ROA dapat dirumuskan sebagai berikut:

$$
\mathrm{ROA}=\frac{\text { Net Income }}{\text { Average Total Assets }}
$$

Keterangan:

ROA

Net Income

Average total assets

b. Variabel Independen Likuiditas

Likuiditas merupakan tingkat kemampuan perusahaan melunasi kewajiban jangka pendek. Dalam penelitian ini likuiditas diproksi- 
kan menggunakan current ratio. Current ratio (CR) merupakan rasio yang menggambarkan kemampuan perusahaan memenuhi kewajiban jangka pendek menggunakan aset lancarnya. CR dapat dirumuskan sebagai berikut:

$$
\mathrm{CR}=\frac{\text { Current Assets }}{\text { Current Liabilities }}
$$

Keterangan:

$\begin{array}{ll}\text { CR } & \text { Current Ratio } \\ \text { Current Assets : } & \text { Total aset lancar perusahaan } \\ \text { Current Liabilities: } & \text { Total utang jangka pendek } \\ & \text { perusahaan }\end{array}$

\section{Solvabilitas}

Solvabilitas merupakan rasio yang mengukur kemampuan perusahaan dalam melunasi kewajiban jangka panjang. Dalam penelitian ini solvabilitas diproksikan menggunakan debt to total asset ratio. Debt to Total Asset Ratio (DTA) menggambarkan seberapa besar aset yang dimiliki perusahaan dibiayai oleh utang. DTA dapat dirumuskan sebagai berikut:

$$
\mathrm{DTA}=\frac{\text { Total Debts }}{\text { Total Assets }}
$$

Keterangan:

DTA

Total Debts

: Debt to Total Asset Ratio

Total Assets

: Total utang perusahaan

: Total aset perusahaan

\section{Manajemen Aset}

Manajemen aset yang diukur dengan rasio aktivitas adalah rasio untuk mengukur efektivitas perusahaan mengelola sumber daya dalam menjalankan kegiatan operasinya. Dalam penelitian ini manajemen aset diproksikan dengan total asset turnover. Total Asset Turnover (TATO) menggambarkan efektivitas penggunaan aset perusahaan dalam menghasilkan pendapatan. TATO dapat dirumuskan sebagai berikut:

$$
\text { TATO }=\frac{\text { Net Sales }}{\text { Average Total Assets }}
$$

Keterangan:

$\begin{array}{lll}\text { TATO } & : & \text { Total Asset Turnover } \\ \text { Net Sales } & : & \text { Penjualan bersih } \\ \text { Average Total Assets } & : & \text { Rata-rata aset perusahaan }\end{array}$

\section{Ukuran Perusahaan}

Ukuran perusahaan merupakan skala yang digunakan untuk menentukan besar kecilnya suatu perusahaan. Dalam penelitian ini ukuran perusahaan dihitung berdasarkan logaritma natural total aset yang dimiliki perusahaan. Perhitungan total aset dengan menggunakan logaritma natural dilakukan untuk mengurangi fluktuasi data dan menyederhanakan nilai total aset tanpa mengubah proporsi dari nilai yang sebenarnya.

$$
\mathrm{UP}=\text { Ln Total Assets }
$$

Keterangan:

UP : Ukuran perusahaan

Ln total assets : Logaritma natural total aset perusahaan

\section{Teknik Analisis Data}

Dalam penelitian ini, pengujian dilakukan dengan analisis regresi berganda untuk meneliti pengaruh antara suatu variabel dependen dengan beberapa variabel independen (Sekaran dan Bougie, 2016). Model regresi yang digunakan adalah sebagai berikut:

$$
\mathrm{ROA}=\alpha+\beta_{1} C R+\beta_{2} D T A+\beta_{3} T A T O+\beta_{4} U P+e
$$

Keterangan:

$\begin{array}{lll}\text { a } & : \text { Konstanta } \\ \beta_{1}, \beta_{2}, \beta_{3}, \beta_{4} & : \text { Loefisien regresi masing-masing } \\ & & \text { Variabel independen } \\ \text { CR } & : & \text { Likuiditas } \\ \text { DTA } & : & \text { Solvabilitas } \\ \text { TATO } & : & \text { Manajemen aset } \\ \text { UP } & : & \text { Ukuran perusahaan } \\ \text { e } & : \text { Standard error }\end{array}$

\section{HASIL DAN PEMBAHASAN}

\section{Objek Penelitian}

Objek yang digunakan dalam penelitian iniadalah perusahaan yang dijadikan sampel berjumlah 44 perusahaan manufaktur. Penelitian dilakukan selama 4 tahun yaitu tahun 2015-2018, sehingga total observasi dalam penelitian ini adalah 176. Berdasarkan kriteria yang telah ditetapkan, maka objek penelitian ini disajikan dalam tabel 1: 
Tabel 1. Pemilihan Sampel

\begin{tabular}{|c|l|c|}
\hline No. & \multicolumn{1}{|c|}{ Kriteria } & $\begin{array}{c}\text { Jumlah Pe- } \\
\text { rusahaan }\end{array}$ \\
\hline 1. & $\begin{array}{l}\text { Perusahaan manufaktur } \\
\text { yang terdaftar di BEI pada } \\
\text { tahun 2015-2018 secara ber- } \\
\text { turut-turut. }\end{array}$ & 134 \\
\hline 2. & $\begin{array}{l}\text { Menerbitkan laporan keu- } \\
\text { angan per 31 Desember dan } \\
\text { telah diaudit. }\end{array}$ & 128 \\
\hline 3. & $\begin{array}{l}\text { Menerbitkan laporan keu- } \\
\text { angan dalam mata uang } \\
\text { Rupiah. }\end{array}$ & 103 \\
\hline 4. & $\begin{array}{l}\text { Mengalami laba pada tahun } \\
\text { 2015-2018 secara berturut- } \\
\text { turut. }\end{array}$ & 65 \\
\hline 5. & $\begin{array}{l}\text { Memiliki nilai total aset di } \\
\text { atas Rp1 Triliun secara ber- } \\
\text { turut-turut. }\end{array}$ \\
\hline Jumlah Perusahaan sebagai Sam- \\
pel
\end{tabular}

Sumber: Data yang diolah

\section{Statistik Deskriptif}

Statistik deskriptif memberikan gambaran atau deskripsi suatu data yang dilihat dari nilai minimum, maksimum, mean, range, dan standar deviasi (Ghozali, 2018). Berikut adalah hasil pengujian statistik deskriptif:

Tabel 2. Statistik Deskriptif

\begin{tabular}{|l|c|c|c|c|c|c|}
\hline & $\mathrm{N}$ & Ran & Min & Max & Mean & Std. De- \\
\hline ROA & 176 &, 552 &, 000 &, 552 &, 10309 &, 0972501 \\
CR & 176 & 8,69 &, 584 & 9,27 & 2,5388 & 1,765906 \\
DTA & 176 &, 749 &, 070 &, 819 &, 41138 &, 1820193 \\
TATO & 176 & 2,69 &, 329 & 3,02 & 1,1547 &, 5151448 \\
UP & 176 & 5,80 & 27,6 & 33,4 & 29,343 & 1,342501 \\
Valid & 176 & & & & & \\
N & & & & & & \\
\hline
\end{tabular}

Sumber: Data yang diolah

Berdasarkan hasil statistik deskriptif pada Tabel 2 kinerja keuangan (ROA) memiliki rata-rata sebesar 0,103097. Artinya, rata-rata rata perusahaan yang menjadi sampel penelitian memiliki kemampuan menghasilkan laba sebesar 10,3097\% dari rata-rata total asetnya.

Berdasarkan hasil statistik deskriptif pada Tabel 2 likuiditas (CR) memiliki nilai rata-rata sebesar 2,538855 yang dapat diartikan bahwa setiap 1 nilai current liability dapat dilunasi dengan 2,538855 jumlah current aset-nya.

Berdasarkan hasil statistik deskriptif pada Tabel 2 solvabilitas (DTA) memiliki rata-rata sebesar 0,411386 yang menunjukkan bahwa tingkat solvabilitas rata-rata perusahaan manufaktur yang menjadi sampel penelitian memiliki aset yang 41,1386 $\%$-nya didanai oleh utang.

Berdasarkan hasil statistik deskriptif pada Tabel 2 manajemen aset memiliki nilai rata-rata sebesar 1,154715 yang berarti rata-rata aset perusahaan dapat menghasilkan penjualan sebesar 1,154715 kali dari aset yang dimiliki.

Berdasarkan hasil statistik deskriptif pada Tabel 2 ukuran perusahaan (UP) memiliki rata-rata sebesar 29,343782 dengan rata-rata total aset sebesar Rp17.984.099.880.933 yang menunjukkan bahwa perusahaan yang menjadi sampel penelitian memiliki ukuran yang relatif besar dilihat dari total aset yang dimiliki.

\section{$\underline{\text { Uji Normalitas }}$}

Hasil uji normalitas data adalah sebagai berikut:

Tabel 3. Hasil Uji Normalitas 1

One-Sample Kolmogorov-Smirnov Test

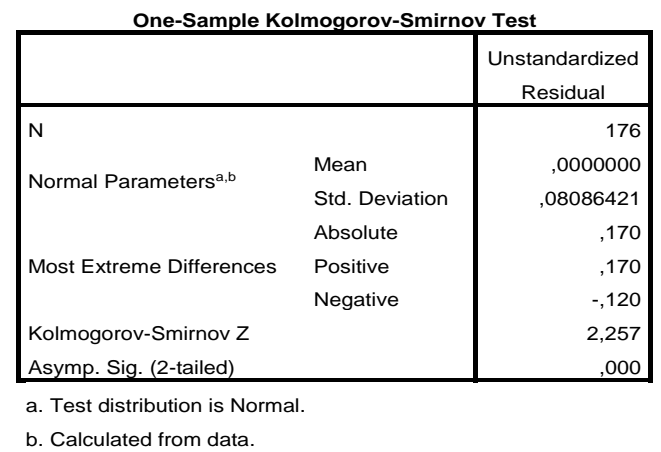

Sumber: Data yang diolah

Hasil yang ditunjukkan pada Tabel 3 menunjukkan nilai Kolmogorov-Smirnov 2,257 dengan besar signifikansi 0,000 , sehingga dapat dinyatakan bahwa semua variabel yang diuji terdistribusi secara tidak normal karena nilai signifikansi lebih kecil dari 0,05. Untuk mengatasi hasil distribusi data yang tidak normal, maka dilakukan transformasi data. Dalam melakukan transformasi data perlu diketahui terlebih dulu variabel mana yang tidak terdistribusi secara normal dengan melihat tabel sebagai berikut: 
Tabel 4. Hasil Uji Normalitas per Variabel

\begin{tabular}{|c|c|c|}
\hline Variabel & $\begin{array}{c}\text { Kolmogorov- } \\
\text { Smirnov Z }\end{array}$ & $\begin{array}{c}\text { Asymp. Sig. (2- } \\
\text { tailed) }\end{array}$ \\
\hline ROA & 2,340 & 0,000 \\
\hline CR & 2,291 & 0,000 \\
\hline DTA & 0,806 & 0,534 \\
\hline TATO & 1,293 & 0,070 \\
\hline UP & 2,225 & 0,000 \\
\hline
\end{tabular}

Sumber: Data yang diolah

Berdasarkan Tabel 4, dengan melihat nilai signifikansi masing-masing variabel, dapat dinyatakan bahwa variabel kinerja keuangan (ROA), likuiditas (CR), dan ukuran perusahaan (UP) merupakan variabel penelitian yang tidak terdistribusi secara normal karena memiliki nilai signifikansinya lebih kecil dari 0,05. Setelah mengetahui variabel yang tidak terdistribusi normal, transformasi data dilakukan dengan melihat bentuk grafik histogram tiap variabel sebagai berikut:

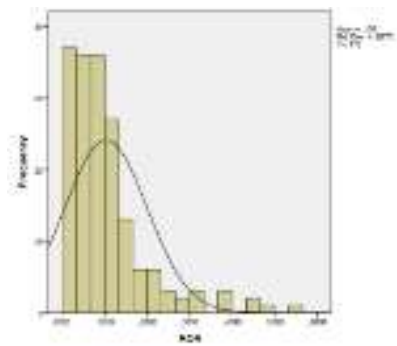

\section{Gambar 4.Grafik Histogram ROA}

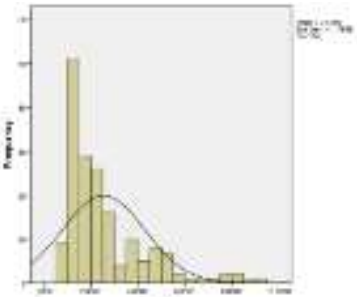

Gambar 5. Grafikik Histogram CR

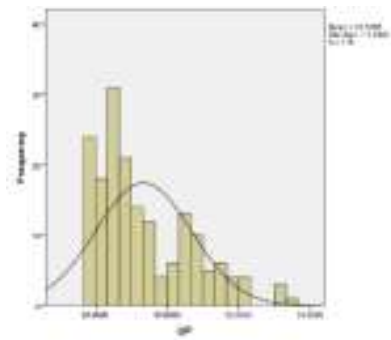

\section{Gambar 6. Grafik Histogram UP}

Berdasarkan hasil grafik histogram dari variabel kinerja keuangan (Gambar 4), likuiditas (Gambar 5), dan ukuran perusahaan (Gambar 6) dapat dinyatakan bahwa ketiga variabel yang tidak terdistribusi normal memiliki bentuk grafik yang sama yaitu moderate positive skewness. Hal tersebut berarti bentuk transformasi data yang diterapkan menggunakan SQRT atau akar kuadrat. Setelah dilakukan transformasi data, uji KolmogorovSmirnov dilakukan kembali dengan menggunakan data hasil transformasi.

Berdasarkan hasil grafik histogram dari variabel kinerja keuangan (Gambar 4), likuiditas (Gambar 5), dan ukuran perusahaan (Gambar 6) dapat dinyatakan bahwa ketiga variabel yang tidak terdistribusi normal memiliki bentuk grafik yang sama yaitu moderate positive skewness. Hal tersebut berarti bentuk transformasi data yang diterapkan menggunakan SQRT atau akar kuadrat. Setelah dilakukan transformasi data, uji KolmogorovSmirnov dilakukan kembali dengan menggunakan data hasil transformasi.

Tabel 5. Hasil Uji Normalitas 2

One-sample Kolmogorov-Smirnov Test

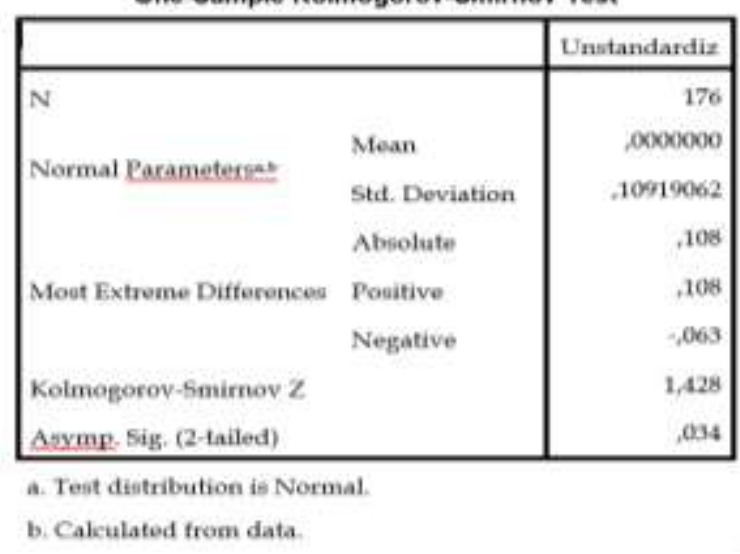

Sumber: Data yang diolah

Hasil pengujian pada Tabel 5 menunjukkan nilai Kolmogorov-Smirno 0,973 dengan besar signifikansi 0,034, sehingga dapat dinyatakan bahwa semua variabel masih belum terdistribusi secara normal karena memiliki signifikansi lebih kecil dari 0,05. Setelah dilakukan transformasi, langkah selanjutnya yaitu perlu mendeteksi adanya outlier dengan melihat nilai batas $z$-score yaitu 3 sampai 4 .

Tabel 6.Data Outlier

\begin{tabular}{|r|l|l|r|c|}
\hline No & \multicolumn{1}{|c|}{ Perusahaan } & Variabel & Tahun & $\begin{array}{c}\text { Z- } \\
\text { score }\end{array}$ \\
\hline 1 & $\begin{array}{l}\text { PT Industri Jamu dan } \\
\text { Farmasi Sido Muncul Tbk }\end{array}$ & SQRT_CR & 2015 & 3,08892 \\
\hline 2 & $\begin{array}{l}\text { PT Wilmar Cahaya Indo- } \\
\text { nesia Tbk }\end{array}$ & TATO & 2016 & 3,62317 \\
\hline 3 & $\begin{array}{l}\text { PT Multi Bintang Indone- } \\
\text { sia Tbk }\end{array}$ & SQRT_ROA & 2017 & 3,28315 \\
\hline 4 & $\begin{array}{l}\text { PT Wilmar Cahaya Indo- } \\
\text { nesia Tbk }\end{array}$ & TATO & 2017 & 3,25915 \\
\hline 5 & $\begin{array}{l}\text { PT Astra International } \\
\text { Tbk }\end{array}$ & SQRT_UP & 2018 & 3,01718 \\
\hline
\end{tabular}


Tabel 7. Hasil Uji Normalitas 3

\begin{tabular}{|c|c|c|}
\hline \multicolumn{3}{|c|}{ One-Sample Kolmogorov-Smirnov Test } \\
\hline & & Unstandardized \\
\hline $\mathrm{N}$ & & 171 \\
\hline \multirow{2}{*}{ Normal Parameters ${ }^{\mathrm{a}, \mathrm{b}}$} & Mean & ,0000000 \\
\hline & Std. Devia- & 10216245 \\
\hline \multirow{3}{*}{ Most Extreme Differences } & Absolute & 083 \\
\hline & Positive & ,083 \\
\hline & Negative &,- 057 \\
\hline Kolmogorov-Smirnov Z & & 1,087 \\
\hline
\end{tabular}

a. Test distribution is Normal.

b. Calculated from data.

Sumber: Data yang diolah

Hasil pengujian normalitas pada Tabel 7 menunjukkan nilai Kolmogorov-Smirnov 1,087 dengan besar signifikansi 0,188, sehingga dapat dinyatakan bahwa semua variabel yang diuji telah terdistribusi secara normal karena memiliki nilai signifikansi lebih besar dari 0,05.

\section{Uji Asumsi Klasik}

\section{Uji Multikolonieritas}

Tabel 8 menunjukkan hasil dari uji multikolonieritas:

Tabel 8. Hasil Uji Multikolonieritas

\begin{tabular}{|ll|c|c|}
\hline \multirow{2}{*}{\multicolumn{2}{|c|}{}} & \multicolumn{2}{c|}{ Collinearity Statistics } \\
\cline { 3 - 4 } Model & & Tolerance & \multicolumn{1}{c|}{ VIF } \\
\hline 1 & (Constant) & & \\
& SQRT_CR &, 274 & 3,647 \\
& DTA &, 268 & 3,738 \\
& TATO &, 955 & 1,047 \\
& SQRT_UP &, 887 & 1,127 \\
\hline
\end{tabular}

a. Dependent Variable: SQRT_ROA

Sumber: Data yang diolah

Berdasarkan hasil tersebut dapat dinyatakan bahwa dalam model regresi tidak terdapat masalah multikolonieritas.

\section{Uji Autokorelasi}

Tabel 9 di bawah ini merupakan hasil uji autokorelasi dengan Run Test:
Tabel 9. Hasil Uji Autokorelasi

\begin{tabular}{|l|r|}
\hline \multicolumn{2}{|c|}{ Runs Test } \\
\hline Test Value $^{\mathrm{a}}$ & Unstandard- \\
Cases $<$ Test Value &,- 00554 \\
Cases $>=$ Test Value & 85 \\
Total Cases & 86 \\
Number of Runs & 171 \\
Z & 81 \\
Asymp. Sig. (2- &,- 843 \\
\hline
\end{tabular}

a. Median

Sumber: Data yang diolah

Berdasarkan hasil uji pada Tabel 9, nilai signifikansi dari hasil uji adalah sebesar 0,399, sehingga dapat disimpulkan tidak terjadi autokorelasi dalam model regresi.

\section{Uji Heteroskedastisitas}

Tabel 10 menunjukkan hasil dari uji heteroskedastisitas:

Tabel 10. Hasil Uji Heteroskedastisitas

\section{Coefficients $^{a}$}

\begin{tabular}{|c|c|c|c|c|c|c|}
\hline & & $\begin{array}{r}\text { Unstar } \\
\text { Coe }\end{array}$ & $\begin{array}{l}\text { dardized } \\
\text { ficients }\end{array}$ & $\begin{array}{l}\text { Stand- } \\
\text { ardized } \\
\text { Coeffi- } \\
\text { cients }\end{array}$ & $\mathrm{t}$ & Sig. \\
\hline & & B & Std. Error & Beta & & \\
\hline 1 & (Constant) & 1,059 & 261 & & 4,057 & ,052 \\
\hline & DTA &,- 045 & 054 &,- 115 &,- 833 & ,406 \\
\hline & TATO & ,042 & ,011 & ,287 & 3,939 & ,061 \\
\hline & SQRT_CR &,- 024 & 020 & -162 & $-1,190$ & ,236 \\
\hline & SQRT_UP & -181 & ,045 &,- 307 & $-4,054$ & ,068 \\
\hline
\end{tabular}

a. Dependent Variable: ABS_UT

Sumber: Data yang diolah

Berdasarkan hasil pada Tabel 10, tidak ada variabel independen yang signifikan mempengaruhi variabel absolut residual, sehingga dapat disimpulkan bahwa model regresi bebas dari masalah heteroskedastisitas.

\section{$\underline{\text { Uji Hipotesis }}$}

Uji Koefisien Korelasi dan Koefisien Determinasi

Analisis korelasi bertujuan untuk mengukur kekuatan hubungan linear antara dua variabel. 
Koefisien determinasi $\left(\mathrm{R}^{2}\right)$ pada intinya mengukur seberapa jauh kemampuan model dalam menerangkan variasi variabel dependen. Berikut adalah hasil uji koefisien korelasi dan determinasi:

Tabel 11. Hasil Uji Koefisien Korelasi dan Determinasi Model Summary ${ }^{b}$

\begin{tabular}{|l|r|r|r|r|}
\hline Model & $R$ & R Square & Adjusted RSquare & $\begin{array}{c}\text { Std. Error of the Es- } \\
\text { timate }\end{array}$ \\
\hline 1 &, $654^{\mathrm{a}}$ &, 428 &, 414 &, 10339 \\
\hline
\end{tabular}

a. Predictors: (Constant), SQRT_UP, TATO, SQRT_CR, DTA

b. Dependent Variable: SQRT_ROA

Berdasarkan Tabel 11, nilai koefisien korelasi (R) sebesar 0,654 atau 65,4\% menunjukkan bahwa hubungan antara variabel likuiditas, solvabilitas, manajemen aset, dan ukuran perusahaan dengan variabel kinerja keuangan memiliki tingkat hubungan yang kuat.

Nilai Adjusted $R$ Square sebesar 0,414 menunjukkan bahwa variabel independen yaitu likuiditas, solvabilitas, manajemen aset, dan ukuran perusahaan mampu menerangkan variabel dependen yaitu kinerja keuangan sebesar 41,4\% sedangkan sebesar 58,6\% dijelaskan oleh variabel-variabel lain yang tidak diujikan dalam penelitian ini.

\section{Uji Signifikansi Simultan (Uji Statistik F)}

Tabel 12 di bawah ini menunjukkan hasil uji statistik F:

Tabel 12. Hasil Uji Statistik F

\begin{tabular}{|c|c|c|c|c|c|c|}
\hline \multicolumn{7}{|c|}{ ANOVAa $^{a}$} \\
\hline \multicolumn{2}{|c|}{ Model } & Sum of & $\mathrm{df}$ & Mean & $\mathrm{F}$ & Sig. \\
\hline & Regres- & 1,327 & 4 & ,332 & 31,032 &, $000^{\mathrm{b}}$ \\
\hline 1 & Residual & 1,774 & 166 & ,011 & & \\
\hline & Total & 3,101 & 170 & & & \\
\hline
\end{tabular}

a. Dependent Variable: SQRT_ROA

b. Predictors: (Constant), SQRT_UP, TATO, SQRT_CR, DTA

Sumber: Data yang diolah

Berdasarkan Tabel 12, terdapat F hitung sebesar 31,032 yang memiliki nilai lebih besar dari F tabel sebesar 2,43 (k;n-k) dengan " $k$ " yang berarti jumlah variabel independen serta " $n$ " yang merupakan jumlah sampel selama periode penelitian $(4 ; 167)$.
Hasil ini menunjukkan model regresi dapat digunakan untuk memprediksi variabel dependen atau fungsi regresi sampel dalam menaksir nilai aktual sudah tepat (model fit). Nilai signifikansi sebesar 0,000 menunjukkan bahwa variabel independen yaitu likuiditas, solvabilitas, manajemen aset, dan ukuran perusahaan secara simultan berpengaruh signifikan terhadap variabel dependen yaitu kinerja keuangan.

\section{Uji Signifikansi Parameter Individual (Uji Statistik t)}

Berikut merupakan hasil uji statistik t:

\section{Tabel 13. Hasil Uji Statistik $\mathbf{t}$}

Coefficients ${ }^{a}$

\begin{tabular}{|c|c|c|c|c|c|c|}
\hline \multicolumn{2}{|c|}{ Model } & \multicolumn{2}{|c|}{ Unstd Coefficients } & \multirow{2}{*}{$\begin{array}{c}\text { Std Coef } \\
\text { Beta }\end{array}$} & \multirow[t]{2}{*}{$\mathrm{t}$} & \multirow[t]{2}{*}{ Sig. } \\
\hline & & B & Std. Error & & & \\
\hline \multirow{5}{*}{1} & (Constant) &,- 929 & ,410 & & $-2,267$ & ,025 \\
\hline & SQRT_CR & ,066 & , 031 & ,239 & 2,131 & ,035 \\
\hline & DTA &,- 116 & ,084 &,- 156 & $-1,379$ & 170 \\
\hline & TATO & 146 & ,017 &, 522 & 8,686 & ,000 \\
\hline & SQRT_UP & 184 & ,070 & , 164 & 2,628 & ,009 \\
\hline
\end{tabular}

a. Dependent Variable: SQRT_ROA

Sumber: Data yang diolah

Berdasarkan Tabel 13, diperoleh persamaan regresi, yaitu:

$\mathrm{ROA}=-0,929+0,066 C R-0,116 D T A+0,146 T A T O$ $+0,184 \mathrm{UP}$

Keterangan:

CR

DTA

TATO

UP

: Likuiditas

: Solvabilitas

: Manajemen aset

: Ukuran perusahaan

Variabel likuiditas (CR) mempunyai nilai koefisien regresi 0,066 yang berarti tiap peningkatan 1\% likuiditas (CR) akan menyebabkan peningkatan kinerja keuangan yang diproksikan dengan return on asset sebesar $6,6 \%$.

Pada hasil uji statistik t untuk variabel likuiditas (SQRT_CR) diperoleh nilai t sebesar 2,131 dengan tingkat signifikansi 0,035. Dengan hasil ini dapat disimpulkan bahwa $\mathrm{Ha}_{1}$ diterima, sehingga likuiditas memiliki pengaruh signifikan terhadap kinerja keuangan. Hal ini sejalan dengan penelitian Mulyani dan Budiman (2017), Alicia (2017), dan Saragih 
(2015) yang menyatakan bahwa likuiditas memiliki pengaruh terhadap kinerja keuangan. Berbeda dengan hasil penelitian Tjahjono (2014) yang menyatakan bahwa likuiditas tidak memiliki pengaruh terhadap kinerja keuangan.

Variabel solvabilitas (DTA) mempunyai nilai koefisien regresi $-0,116$ yang berarti bahwa tiap peningkatan $1 \%$ solvabilitas (DTA) akan menyebabkan penurunan kinerja keuangan yang diproksikan dengan return on asset sebesar $11,6 \%$.

Pada hasil uji statistik $\mathrm{t}$ untuk variabel solvabilitas (DTA), diperoleh nilai t sebesar -1,379 dengan tingkat signifikansi 0,170 . Hasil ini menunjukkan $\mathrm{Ha}_{2}$ ditolak, dengan kata lain solvabilitas tidak berpengaruh terhadap kinerja keuangan. Hasil ini sesuai dengan hasil penelitian Tjahjono (2014) yang menyatakan bahwa solvabilitas tidak memiliki pengaruh terhadap kinerja keuangan yang diproksikan dengan ROA. Berbeda dengan hasil penelitian Gunde,dkk (2017) yang menyatakan bahwa solvabilitas memiliki pengaruh yang signifikan terhadap profitabilitas yang diproksikan dengan ROA.

Solvabilitas yang diproksikan dengan debt to total asset menunjukkan seberapa besar jumlah aset perusahaan yang didanai dengan utang. Semakin rendah tingkat DTA menandakan semakin sedikit jumlah aset yang diperoleh menggunakan utang. Semakin sedikit jumlah utang mengakibatkan beban utang yang ditanggung juga akan semakin sedikit sehingga dapat memaksimalkan laba yang diperoleh perusahaan. Akan tetapi dalam penelitian ini, solvabilitas (DTA) tidak memiliki pengaruh signifikan terhadap kinerja keuangan.

Hal tersebut disebabkan karena sebagian besar peningkatan utang perusahaan diiringi dengan peningkatan kegiatan produksinya. Sebanyak 115 dari 171 observasi $(67,25 \%)$ mengalami rata-rata kenaikan jumlah utang sebesar $23,23 \%$. Dana yang berasal dari utang dapat digunakan oleh perusahaan untuk meningkatkan produksi yang dapat diukur dengan beban pokok penjualan. Sebanyak 90 dari 115 observasi $(78,26 \%)$ mengalami kenaikan beban pokok penjualan dengan nilai rata-rata 16,01\%. Dari 90 observasi, sebanyak 71 observasi (78,89\%) mengalami peningkatan laba tahun berjalan dengan nilai rata-rata kenaikan sebesar $114,64 \%$ yang dapat diartikan bahwa perusahaan mengusahakan peningkatan kegiatan operasionalnya untuk memperoleh pendapatan dan laba.

Hal lain yang dapat menyebabkan solvabilitas tidak berpengaruh terhadap kinerja keuangan berdasarkan observasi yaitu terdapat sebagian perusahaan yang mengalami peningkatan utang tetapi tidak memusatkan pendanaan untuk kegiatan operasional, melainkan untuk kegiatan investasi. Sebanyak 115 dari 171 observasi $(67,25 \%)$ mengalami rata-rata kenaikan jumlah utang sebesar 23,23\%. Dari 115 observasi tersebut, sebanyak 44 observasi $(38,26 \%)$ mengalami penurunan laba tahun berjalan dengan nilai rata-rata penurunan laba sebesar 34,03\%. Dari 44 observasi yang mengalami penurunan laba tahun berjalan, sebanyak 27 observasi $(61,36 \%)$ mengalami peningkatan pengeluaran arus kas investasi lebih besar daripada peningkatan arus kas dari hasil operasional, dengan rata-rata kenaikan nilai arus kas investasi sebesar $140,8 \%$. Hal ini menunjukkan perusahaan yang mengalami peningkatan utang, memanfaatkan dana yang diperoleh untuk meningkatkan kegiatan investasi.

Variabel manajemen aset (TATO) menunjukkan nilai koefisien regresi 0,146 yang menandakan tiap peningkatan $1 \%$ manajemen aset (TATO) akan membuat kinerja keuangan yang diproksikan dengan return on asset meningkat sebesar $14,6 \%$.

Pada hasil uji statistik $t$ untuk variabel manajemen aset (TATO), diperoleh nilai $t$ sebesar 8,686 dengan tingkat signifikansi 0,000. Hasil ini menunjukkan bahwa $\mathrm{Ha}_{3}$ diterima, yaitu manajemen aset memiliki pengaruh signifikan terhadap kinerja keuangan. Hasil ini sejalan dengan hasil penelitian Sinaga (2018) dan Indriyani,dkk (2017) yang menyatakan bahwa manajemen aset (TATO) memiliki pengaruh terhadap kinerja keuangan (ROA). Namun, hasil ini berbeda dengan hasil penelitian yang dilakukan Noormulianingsih dan Swandari (2016) yang menyatakan bahwa TATO tidak memiliki pengaruh yang signifikan terhadap ROA.

Variabel ukuran perusahaan (UP) mempunyai nilai koefisien regresi sebesar 0,184 yang menunjukkan bahwa tiap peningkatan 1\% ukuran perusahaan (UP) akan menyebabkan kinerja keuangan yang diproksikan dengan return on asset meningkat sebesar $18,4 \%$.

Pada hasil uji statistik $\mathrm{t}$ untuk variabel ukuran perusahaan (UP), diperoleh nilai $t$ sebesar 2,628 dengan tingkat signifikansi 0,009. Hasil ini menunjukkan bahwa $\mathrm{Ha}_{4}$ diterima, yaitu ukuran perusahaan berpengaruh signifikan terhadap kinerja keuangan. Hasil ini mendukung hasil penelitian Tisna dan Agustami (2016) dan Isbanah (2015) yang menyatakan bahwa ukuran perusahaan memiliki pengaruh terhadap kinerja keuangan. Namun, hasil ini tidak sesuai dengan hasil penelitian Epi (2017) yang menyatakan bahwa ukuran perusahaan tidak berpengaruh terhadap kinerja keuangan. 


\section{SIMPULAN}

Simpulan yang diperoleh atas penelitian ini adalah:

1. $\mathrm{Ha}_{1}$ diterima, yang berarti variabel likuiditas berpengaruh signifikan terhadap kinerja keuangan. Hal ini terbukti dari nilai $\mathrm{t}$ sebesar 2,131 dengan tingkat signifikansi lebih kecil dari 0,05 yaitu 0,035 . Hasil penelitian ini sejalan dengan penelitian Mulyani dan Budiman (2017), Alicia (2017), dan Saragih (2015) yang berpendapat bahwa likuiditas berpengaruh terhadap kinerja keuangan.

2. $\mathrm{Ha}_{2}$ ditolak, yang berarti variabel solvabilitas tidak berpengaruh terhadap kinerja keuangan. Hasil uji $\mathrm{t}$ menunjukkan nilai $\mathrm{t}$ sebesar $-1,379$ dengan tingkat signifikansi yaitu 0,170. Hasil penelitian ini mendukung penelitian Tjahjono (2014) dan Utami dan Pardanawati (2016) yang berpendapat bahwa solvabilitas tidak berpengaruh terhadap kinerja keuangan.

3. $\mathrm{Ha}_{3}$ diterima, yang berarti variabel manajemen aset berpengaruh signifikan terhadap kinerja keuangan. Hasil uji $\mathrm{t}$ menunjukkan nilai $\mathrm{t}$ sebesar 8,686 dengan tingkat signifikansi yaitu 0,000 . Hasil penelitian ini sejalan dengan penelitian Sinaga (2018) dan Indriyani,dkk (2017) yang menyatakan bahwa manajemen aset memiliki pengaruh terhadap kinerja keuangan.

4. $\mathrm{Ha}_{4}$ diterima, yang berarti variabel ukuran perusahaan berpengaruh secara signifikan terhadap kinerja keuangan. Hasil uji $t$ menunjukkan nilai $\mathrm{t}$ sebesar 2,628 dengan tingkat signifikansi yaitu 0,009. Hasil penelitian ini mendukung penelitian Tisna dan Agustami (2016) dan Isbanah (2015) yang berpendapat bahwa ukuran perusahaan berpengaruh terhadap kinerja keuangan.

5. Variabel likuiditas, solvabilitas, manajemen aset, dan ukuran perusahaan secara simultan berpengaruh signifikan terhadap kinerja keuangan (ROA). Hasil penelitian ini mendukung penelitian Utami dan Pardanawati (2016) yang menyatakan bahwa likuiditas, solvabilitas, dan manajemen aset secara simultan berpengaruh signifikan terhadap kinerja keuangan (ROA).

Keterbatasan penelitian ini adalah sebagai berikut:

1. Objek yang digunakan penelitian ini adalah perusahaan manufaktur terdaftar di BEI pada periode 2015-2018, sehingga hasil penelitian ini tidak dapat digeneralisasi untuk semua perusahaan yang listing di BEI.
2. Terdapat variabel lain yang tidak digunakan dalam penelitian ini $(58,6 \%$ atau $100 \%-41,4 \%)$ yang memiliki pengaruh terhadap kinerja keuangan. Hal ini ditunjukkan dengan nilai Adjusted $R$ Square dalam penelitian ini yang hanya sebesar 0,414 .

Saran yang dapat diajukan untuk penelitian selanjutnya adalah sebagai berikut:

1. Memperluas objek penelitian yang diteliti dengan menggunakan atau menambahkan sektor lain dan memperpanjang periode penelitian.

2. Menambahkan variabel independen lain yang diprediksi memiliki pengaruh terhadap kinerja keuangan, seperti corporate social responsibility, good corporate governance, dan pertumbuhan penjualan.

Implikasi dari penelitian ini adalah:

1. Bagi perusahaan, harus dapat memaksimalkan penggunaan aset yang dimiliki dan berhati-hati dalam pengambilan keputusan kredit sehingga dapat meningkatkan kinerja keuangannya.

2. Bagi investor dan kreditur, dapat mempertimbangkan likuiditas dan penggunaan aset perusahaan untuk menilai kinerja keuangan perusahaan dalam pengambilan keputusan melakukan investasi maupun pemberian kredit.

\section{REFERENCES}

Akbar, S., Nurdin, dan Azib.(2017). Pengaruh Debt to Asset Ratio dan Debt to Equity Ratio terhadap Return on Asset.Prosiding Manajemen, 3(2), 11931198.

Alicia, D. D. (2017). Pengaruh Likuiditas terhadap Profitabilitas pada Perusahaan Sub Sektor Semen yang Terdaftar di Bursa Efek Indonesia periode 2011-2015.Jurnal Online Mahasiswa (JOM) Bidang Akuntansi, 2(2), 1-11.

Ambarwati, N. S., Yuniarta, G. A., dan Sinarwati, N. K. (2015). Pengaruh Modal Kerja, Likuiditas, Aktivitas, dan Ukuran Perusahaan terhadap Profitabilitas pada Perusahaan Manufaktur yang Terdaftar di Bursa Efek Indonesia.Jurnal Ilmiah Mahasiswa Akuntansi, 3(1), 1-11.

Badan Koordinasi Penanaman Modal.(2018). Press Release TW III 2018.Diunduh pada tanggal 13 Juni 2019, www.bkpm.go.id/images/uploads/file_siaran_ pers/Paparan_Bahasa_Indonesia_Press_Release _TW_III_2018.pdf. (2018).

Epi, Y. (2017). Pengaruh Ukuran Perusahaan, 
Struktur Kepemilikan Manajerial dan Manajemen Laba terhadap Kinerja Perusahaan Property dan Real Estate yang Terdaftar pada Bursa Efek Indonesia. Riset dan Jurnal Akuntansi, 1(1), 1-7.

Fajrin, P. H., dan Laily, N. (2016).Analisis Profitabilitas dan Likuiditas terhadap Kinerja Keuangan PT. Indofood Sukses Makmur, Tbk. Jurnal Ilmu dan Riset Manajemen, Vol.5 No.6.

Ghozali, I. (2018). Aplikasi Analisis Multivariate dengan Program IBM SPSS 25. Semarang: Badan Penerbit Universitas Diponegoro.

Gunde, Y. M., Murni, S., dan Rogi, M. H. (2017).Analisis Pengaruh Leverage terhadap Profitabilitas Pada Perusahaan Manufaktur Sub Industri Food and Beverages yang Terdaftar di BEI (Periode 2012-2015).Jurnal EMBA, 5(3), 41854194.

Hantono.(2016). Pengaruh Ukuran Perusahaan, Total Hutang, Current Ratio, terhadap Kinerja Keuangan dan Harga Saham sebagai Variabel Moderating.Jurnal Wira Ekonomi Mikroskil, 6(1), 35-43.

Ikatan Akuntan Indonesia.(2018). Standar Akuntansi Keuangan. Jakarta: Penerbit Salemba.

Indriyani, I., Panjaitan, F., dan Yenfi. (2017). Analisis Pengaruh Current Ratio dan Total Asset Turnover terhadap Return On Asset. Jurnal Ilmiah Akuntansi Bisnis \& Keuangan STIE-IBEK, 10(2).

Hardum, S. E., (2019). Industri manufaktur berperan penting genjot investasi.Didapat dari www.beritasatu.com/ekonomi/531583-industrimanufaktur-berperan-penting-genjotinvestasi.html.

Rahayu, R. (2018). Inilah 92 Emiten Peraih Indonesia Best Public Company 2018.Didapat dari www.wartaekonomi.co.id/read189333/inilah92-emiten-peraih-indonesia-best-publiccompany-2018.html.

Isbanah, Y. (2015). Pengaruh ESOP, Leverage, and Ukuran Perusahaan terhadap Kinerja Keuangan Perusahaan di Bursa Efek Indonesia.Journal of Research in Economics and Management, 15(1), 2841.

Jumingan.(2006). Analisis Laporan Keuangan.Jakarta: PT. Bumi Aksara.

Kieso, D. E., Weygandt, J. J., dan Warfield, T. D. (2017). Intermediate Accounting Third Edition. New Jersey: John Wiley dan Sons.

Kustodian Sentral Efek Indonesia.(2018). Peraturan KSEI No.I-E tentang Single Identification (SID). Diunduh pada tanggal 13 Juni 2019, www.ksei.co.id/files/Peraturan_KSEI_No._IE_tentang_Single_Investor_Identification_(SID). pdf. (2018).

Mulyani, E. L., dan Budiman, A. (2017). Analisis Pengaruh Kualitas Aset, Likuiditas, Solvabilitas, Aktivitas dan Non Performing Loan terhadap Kinerja Keuangan. Jurnal Ekonomi Manajemen, 3(1), 11-17.

Noormuliyaningsih, T., dan Swandari, F. (2016).Pengaruh Rasio Aktivitas dan Rasio Leverage terhadap Tingkat Profitabilitas. Jurnal Wawasan Manajemen, 4(1),65-73.

Novitasari, P., dan Herlambang, L. (2015). Pengaruh Current Ratio, Total Asset Turnover, Debt to Equity Ratio, dan Return on Equity terhadap Harga Perusahaan pada Perusahaan yang Terdaftar di JII Periode 2009-2013. JESTT, 2(4), 356-371.

Raharjaputra, H. S. (2009). Manajemen Keuangan dan Akuntansi untuk Eksekutif Perusahaan. Jakarta: Salemba Empat.

Sabil.(2016). Peranan Rasio Likuiditas, Solvabilitas, Rentabilitas terhadap Kinerja Keuangan pada K.I.A Tour \& Travel Jakarta.Moneter, (3)1, 54-65.

Taqiyyah, B. (2012). Saham ADES meroket terdongkrak kinerja cemerlang.Didapat dari www.investasi.kontan.co.id/news/saham-adesmeroket-terdongkrak-kinerja-cemerlang.

Saragih, M. Siahaan, Y., Purba, R., dan Supitriyani. (2015). Pengaruh Current Ratio terhadap Return On Asset pada Perusahaan Sektor Aneka Industri yang Listing di Bursa Efek Indonesia. Jurnal Financial, 1(1), 19-24.

Sekaran, U., dan Bougie, R. (2016). Research Methods for Business. New Jersey: John Wiley dan Sons.

Sinaga, C. D. (2018). Pengaruh Current Ratio, Total Asset Turnover, Net Profit Margin dan Inventory Turnover terhadap Return On Asset pada Perusahaan Manufaktur Sektor Pertambangan Dibursa Efek Indonesia Periode 2011-2016. Jurnal Akuntansi FE UMRAH, 1-11.

Solechan, A. (2017). Pengaruh Efisiensi Modal Intelektual terhadap Kinerja Keuangan Perusahaan di Indonesia.Jurnal Kajian Akuntansi, 1(1), 87-100.

Supardi, H., Suratno, H., dan Suyanto. (2016). Pengaruh Current Ratio, Debt to Total Asset Ratio, Total Asset Turnover dan Inflasi terhadap Return On Asset. Jurnal Ilmiah Akuntansi Fakultas Ekonomi, 2(2), 16-27.

Tisna, G. A., dan Agustami, S. (2016). Pengaruh Good Corporate Governance dan Ukuran Perusahaan terhadap Kinerja Keuangan Perusahaan.Jurnal Riset Akuntansi dan Keuangan, 4(2), 1035-1046. 
Tjahjono, R. S. (2014). Faktor-faktor yang Mempengaruhi Kinerja Keuangan pada Perusahaan Manufaktur yang Terdaftar di Bursa Efek Indonesia.Jurnal Bisnis dan Akuntansi, 16(3), 1-22.

Utami, W. B., dan Pardanawati, S. L. (2016). Pengaruh Likuiditas, Solvabilitas dan Manajemen Aset terhadap Kinerja Keuangan Pada Perusahaan Go Public yang Terdaftar Dalam Kompas 100 di Indonesia. Jurnal Akuntansi dan Pajak, 17(01), 63-72.

Weygandt, J. J., Kimmel, P. D., dan Kieso, D. E. (2015). Financial Accounting IFRS Edition (3th Edition). New Jersey: John Wiley dan Son, Inc. 